\title{
Peran Perawat dalam Mengoptimalkan Kesehatan dan Keselamatan Kerja di Rumah Sakit (K3RS)
}

\author{
Nikita Gina Chesena Sembiring \\ nikitagina.ng@gmail.com
}

\section{LATAR BELAKANG}

Rumah sakit merupakan tempat kerja yang berpotensi tinggi terhadap terjadinya kecelakaan kerja. Terdapat bahan mudah terbakar, gas medis, radiasi pengion dan bahan kimia, yang membutuhkan perhatian serius terhadap keselamatan pasien,staf dan umum (Sarastuti, 2016). Perawat adalah suatu profesi yang mulia, karena memerlukan kesabaran dan ketenangan dalam melayani pasien yang sedang menderita sakit. Seorang perawat harus dapat melayani pasien dengan sepenuh hati. Perawat adalah tenaga kesehatan yang paling besar jumlahnya dan paling lama kontak dengan pasien, sehingga sangat berisiko dengan pekerjaannya, namun banyak perawat yang tidak menyadari risiko yang mengancam dirinya dan melupakan keselamatan dan kesehatan kerja (K3).

Kecelakaan adalah kejadian tidak terduga yang disebabkan oleh tindakan yang tidak aman dan kondisi tidak aman (Heinrich,1930). 85\% kecelakaan disebabkan oleh faktor manusia dengan tindakan yang tidak aman. Tindakan tidak aman adalah tindakan yang dapat membahayakan pekerja itu sendiri maupun orang lain yang dapat menyebabkan terjadinya kecelakaan yang disebabkan oleh berbagai hal seperti tidak menggunakan APD, tidak mengikuti prosedur kerja, tidak mengikuti peraturan keselamatan kerja dan bekerja tidak hati-hati,dimana setiap 300 tindakan yang tidak aman, akan terjadi 1 kali kecelakaan yang mengakibatkan kehilangan hari kerja.

Di Indonesia penelitian dari Joseph tahun 2005-2007 mencatat bahwa angka Kecelakaan Akibat Kerja (KAK) needle stick injury (NSI) mencapai 38-73\% dari total petugas kesehatan dan prevalensi gangguan mental emosional 17,7\% pada perawat di suatu Rumah Sakit di Jakarta berhubungan bermakna dengan stressor kerja (Kepmenkes RI,2010,p.11). Kecelakaan kerja menjadi salah satu masalah urgen di lingkungan Rumah Sakit. Hal ini diakibatkan karena Rumah 
Sakit merupakan suatu unit pelayanan kesehatan yang memberikan pelayanan pada semua bidang dan jenis penyakit.

Kesehatan dan keselamatan kerja adalah salah satu isu penting di dunia kerja saat ini. Kesehatan dan keselamatan kerja adalah kegiatan yang dirancang untuk menjamin kesehatan di tempat kerja. Keselamatan kerja diartikan sebagai upaya-upaya yang ditujukan untuk melindungi pekerja; menjaga keselamatan orang lain; melindungi peralatan, tempat kerja. Risiko bahaya dalam kegiatan rumah sakit dalam aspek kesehatan kerja, antara lain berasal dari sarana kegiatan di poliklinik, bangsal, laboratorium, kamar rontgent, dapur, laundry, ruang medical record, lift, generator-set, penyalur petir, alat-alat kedokteran, pesawat uap atau bejana dengan tekanan, istalasi peralatan listrik, instalasi proteksi kebakaran, air limbah, sampah medis dan sebagainya.

Pelaksanaan manajemen hyperkes dan kesehatan keselamatan kerja di Rumah Sakit berupaya meminimalisasi kerugian yang timbul akibat PAK dan KAK, perlindungan tenaga kerja serta pemenuhan peraturan perundangan K3 yang berlaku (law-compliance). Fungsi perencanaan dalam hyperkes dan kesehatan dan keselamatan kerja di Rumah Sakit, merupakan bagian integral dari perencanaan manajemen perusahaan secara menyeluruh, yang dilandasi oleh komitmen tertulis atau kesepakatan manajemen puncak.Fungsi pengawasan atau pengendalian didalam hyperkes dan kesehatan dan keselamatan kerja di Rumah Sakit merupakan fungsi untuk mengetahui sejauh mana pekerja dan pengawas mematuhi kebijakan kesehaan dan keselamatan kerja di Rumah Sakit yang telah ditetapkan oleh pemimpin serta dijadikan dasar penilaian untuk sertifikasi.

Pemerintah melakukan berbagai upaya untuk mengatasi kecelakaan kerja di Rumah Sakit, salah satunya dengan dikeluarkannya Undang-Undang Nomor 23 Tahun 1992 dan Undang-Undang Nomor 36 Tahun 2009 tentang Penerapan Kesehatan dan Keselamatan Kerja di Rumah Sakit (Kepmenkes RI,2010, p.8).

Upaya untuk meningkatkan derajat kesehatan dan keselamatan, pekerja mendapatkan perhatian dari seluruh dunia dengan diprioritaskan occupational health kesehatan kerja dalam kebijakan Health People 2000. Kebijakan yang bersifat global ini ditujukan untuk memperbaiki status kesehatan pekerja, mengurangi faktor risiko di tempat kerja, memperbaiki dan 
meningkatkan pelayanan kesehatan kerja, serta mengurangi terjadinya kecelakaan dan penyakit akibat kerja (Eigsti, Guire \& Stone, 2002).

Tujuan kesehatan dan keselamatan kerja adalah mencegah mengurangi, bahkan meminimalkan risiko penyakit dan kecelakaan akibat kerja serta meningkatkan derajat kesehatan para pekerja sehingga produktivitas kerja meningkat.

Perawat merupakan salah satu sumber daya manusia terpenting dalam manajemen keselamatan kerja karena merupakan profesi yang memberikan pelayanan yang konstan dan terus-menerus 24 jam kepada pasien setiap hari. Oleh karena itu pelayanan keperawatan sebagai bagian integral dari pelayanan kesehatan dan keselamatan kerja (K3) jelas mempunyai kontribusi yang sangat menentukan tinggi rendahnya angka kejadian kecelakaan kerja. Sehingga setiap upaya untuk meningkatkan kualitas kesehatan dan keselamatan kerja (K3) harus juga disertai upaya untuk meningkatkan kualitas pelayanan keperawatan melalui pengoptimalan peran perawat dalam pencegahan dan penanganan kecelakaan kerja.

\section{METODE}

Kajian ini dilakukan dengan metode menganalisis dari berbagai sumber bacaan. Baik dari berbagai jurnal online, e-book yang memiliki hubungan dengan keselamatan dan kesehatan kerja dalam keperawatan.

Penulisan kajian ini melakukan metode perbandingan antar satu artikel dengan artikel lainnya. Kemudian perbandingannya ditulis secara beraturan dalam hasil dari kajian. Dengan isi yang akan dibadingkan tetap berhubungan dengan keselamatan dan kesehatan kerja dalam keperawatan.

\section{HASIL}

Dari beberapa sumber yang didapat baik dari jurnal online, skripsi. Ditemukan bahwa beberapa negara membuktikan bahwa Rumah Sakit adalah salah satu tempat kerja yang berbahaya dan perawat adalah salah satu petugas kesehatan yang berisiko untuk mengalami gangguan kesehatan dan keselamatan kerja akibat dari pekerjaannya. 
National Safety Council (dalam Kepmenkes RI, 2007, p.4) menyebutkan bahwa terjadinya kecelakaan di rumah sakit $41 \%$ lebih besar dari pekerja di industri lain.Selain itu Annizar (2012, p.3) menyatakan bahwa secara umum sebanyak 80-85 \% kecelakaan kerja disebabkan oleh perilaku yang tidak aman. Data dan fakta Kesehatan dan Keselamatan Kerja Rumah Sakit (K3RS) secara global yang dipaparkan oleh WHO (dalam Kepmenkes RI, 2010, p.10) menyebutkan bahwa dari 35 juta petugas kesehatan, 3 juta terpajan patogen darah dan lebih dari $90 \%$ terjadi di negara berkembang.

Berdasarkan data dari World Health Organization (WHO) : Dari 35 juta pekerja kesehatan 3 juta terpajan patogen darah (2 juta terpajan virus HBV, 0,9 juta terpajan virus HBC dan 170,000 terpajan virus HIV/ AIDS). Dapat terjadi : 15,000 HBC, 70,000 HBB \& 1000 kasus HIV. Lebih dari $90 \%$ terjadi di negara berkembang.8-12\% pekerja rumah sakit, sensitif terhadap lateks. Probabilitas penularan HIV setelah luka tusuk jarum suntik yang terkontaminasi HIV 4: 1000. Risiko penularan HBV setelah luka tusuk jarum suntik yang terkontaminasi HBV 27-37: 100. Risiko penularan HCV setelah luka tusuk jarum suntik yang mengandung HCV 3 - 10 : 100 (Sunandar, 2017).

National Patient Safety Agency (2017) melaporkan dalam rentang waktu Januari sampai dengan Maret 2017 angka kejadian insiden yang dilaporkan dari negara Inggris sebanyak 460.862 kejadian diantaranya adalah angka tertinggi pada insiden kecelakaan pasien sebanyak 76.621 kejadian atau sebanyak $17 \%$.

Penyakit Akibat Kerja (PAK) dan Kecelakaan Kerja (KK) pada petugas kesehatan dan non kesehatan di Indonesia belum terekam dengan baik, data kecelakaan di Rumah Sakit belum ada laporannya. Hasil survei Nopember 2014, dalam rentang tahun 2009 sampai tahun 2011, terdapat 2 orang perawat di Ruangan Interna menderita penyakit Hepatitis, diduga tertular dari pasien, kemudian dilanjutkan dengan survei pada bulan Januari 2015 di Ruang ICU dan Interna, pada 10 perawat hasilnya pencapaian rata-rata keselamatan dan kesehatan kerja perawat di Rumah Sakit Benyamin Guluh Kab. Kolaka adalah 56\%, yang artinya K3RS belum optimal (Standar Kemenkes MFK dan PPI 100\%).

Kejadian penyakit infeksi di rumah sakit dianggap sebagai suatu masalah serius karena mengancam kesehatan dan kesejahteraan pasien dan petugas kesehatan secara global (Luo, et all, 
2010). Penelitian menunjukan bahwa rata-rata risiko transmisi virus melalui Blood-borne pada kecelakaan tertusuk jarum yaitu 30\% untuk virus Hepatitis B, virus Hepatitis C yaitu 3\% dan kurang lebih 0,3\% untuk virus HIC (Weston, 2008). WHO (2002) mengestimasikan bahwa sekitar 2,5\% petugas kesehatan diseluruh dunia menghadapi pajanan HIV dan sekitar 40\% menghadapi pajanan virus Hepatitis B dan Hepatitis C (Sadoh, et. all, 2006) dan 90\% dari infeksi yang dihasilkan dari pajanan tersebut berada di negara berkembang (Reda, et.all, 2010).

Penelitian yang dilakukan di RSUD Kabupaten Cianjur (Hermana, 2006) menyebutkan bahwa jumlah perawat yang mengalami luka tusuk jarum dan benda tajam lainnya adalah cukup tinggi yaitu $61,34 \%$.

Di Australia, diantara 813 perawat, $87 \%$ pernah low back pain, prevalensi $42 \%$ dan di AS, insiden cedera musculoskeletal 4,62/100 perawat per tahun. Cedera punggung menghabiskan biaya kompensasi terbesar, yaitu lebih dari 1 milliar dollar per tahun (Pedoman Manajemen Kesehatan dan Keselamatan Kerja (K3) di Rumah Sakit (Depkes, 2006). Data Riskesdas tahun 2018, untuk kasus kecelakaan kerja yang terjadi di tempat-tempat umum seperti rumah sakit secara nasional sebesar 9,2\%, untuk provinsi Sulawesi Utara sebesar 8,3\% dan kecelakaan kerja yang terjadi di Kota Kotamobagu sebesar 5\% (Kemenkes RI, 2018)Hasil penelitian Trisilawati (2006), di RSUD Dr. Haryoto Lumajang terdapat angka kejadian KAK yang cukup besar yaitu 57,83\% dan PAK sebesar 21,69\%. Masalah K3 tersebut terjadi karena berbagai sebab diantaranya adalah pengelolaan data dan informasi yang kurang baik terhadap setiap kejadian KAK dan PAK. Selain itu juga disebabkan karena sebagian besar tenaga RS tidak pernah mengikuti penyuluhan, diklat atau seminar K3 sehingga sebagian besar dari mereka tidak tahu bagaimana upaya penanggulangan kejadian KAK dan PAK maupun upaya penanggulangan masalah K3 lainnya.

Penggunaan APD pada perawat masih dikategorikan kurang. Siburan (2012) menunjukkan bahwa sikap perawat dalam penggunaan APD masih kurang, yaitu sebanyak $53,30 \%$ perawat memiliki sikap negatif dan 46,7\% yang memiliki sikap positif. Ningsih (2014) menemukan bahwa perilaku penggunaan APD yang baik pada perawat hanya sebesar 47,6\% dan sisanya 52,4\% menunjukkan penggunaan APD yang kurang baik.

Biro statistik Ketenagakerjaan dan konsul nasional asuransi America 2013menyimpulkan pada rumah sakit di Amerika setiap 100 jam kerja terjadi 6,8 kejadian kecelakaan kerja dan 
penyakit akibat kerja atau PAK. Angka ini menempatkan kecelakaan kerja dan PAK di rumah sakit sedikit lebih tinggi dibanding dengan kecelakaan kerja dan PAK di sektor lainnya seperti sektor konstruktif manufaktur dan pelayanan professional dan bisnis lainnya.

\section{PEMBAHASAN}

Dalam Undang-Undang Republik Indonesia Nomor 36 Tahun 2009 tentang kesehatan, pasal 165: pengelola tempat kerja wajib melakukan segala bentuk upaya Kesehatan melalui upaya pencegahan peningkatan pengobatan dan pemulihan bagi tenaga kerjanya. Upaya kesehatan kerja ditunjukkan untuk melindungi pekerja agar hidup sehat dan terbebas dari gangguan kesehatan serta pengaruh buruk yang diakibatkan oleh pekerjaan sehingga sudah seharusnya pihak pengelola Rumah Sakit menerapkan upaya upaya kesehatan dan keselamatan kerja (K3) di Rumah Sakit.

Undang-Undang Nomor 44 Tahun 2009 tentang Rumah Sakit pasal 7 ayat 1, bahwa Rumah Sakit harus memenuhi persyaratan lokasi, bangunan, prasarana, sumber daya manusia, kefarmasian, dan peralatan, persyaratan-persyaratan tersebut salah satunya harus memenuhi unsur keselamatan dan kesehatan kerja (K3) di dalamnya. Rumah sakit yang tidak memenuhi persyaratan persyaratan tersebut tidak diberi Izin Mendirikan, dicabut atau tidak diperpanjang izin operasional Rumah Sakit (pasal 17) (Menkes RI, 2009)

\section{A. Pengertian Kesehatan dan Keselamatan Kerja}

Kesehatan kerja merupakan suatu kondisi yang bebas dari gangguan secara fisik dan psikis yang disebabkan oleh lingkungan kerja. Risiko kesehatan dapat terjadi karena adanya faktor faktor dalam lingkungan kerja yang bekerja melebihi periode waktu yang ditentukan dan lingkungan yang menimbulkan stres atau gangguan fisik. Sementara keselamatan kerja adalah keselamatan yang berhubungan dengan aktivitas kerja manusia baik pada industri manufaktur yang melibatkan mesin, peralatan penanganan material pesawat uap dan bejana bertekanan, alat kerja bahan dan proses pengolahannya landasan tempat kerja dan lingkungannya serta cara-cara melakukan pekerjaan, maupun industri jasa, yang melibatkan peralatan berteknologi canggih seperti lift, eskalator peralatan pembersih gedung sarana transportasi dan lain-lain. 
Menurut Atika Puspita Sari (2012) Keselamatan kerja telah menjadi salah satu hak asasi manusia yang harus dilindungi oleh pemerintah dan dihargai oleh anggota masyarakat lainnya. Tenaga kerja harus memperoleh perlindungan dari berbagai soal di sekitarnya dan pada dirinya yang dapat menimpa atau mengganggu dirinya serta pelaksanaan pekerjaannya (Mondy 2008).

Keselamatan dan kesehatan kerja (K3) difilosofikan sebagai suatu pemikiran dan upaya untuk menjamin keutuhan dan kesempurnaan baik jasmani maupun rohani tenaga kerja pada khususnya dan manusia pada umumnya, hasil karya dan budayanya menuju masyarakat makmur dan sejahtera. Secara keilmuan kesehatan dan keselamatan kerja adalah ilmu pengetahuan dan penerapan dalam usaha mencegah kemungkinan terjadinya kecelakaan dan penyakit akibat kerja. Kesehatan dan keselamatan kerja (K3) merupakan suatu upaya perlindungan kepada tenaga kerja dan orang lain yang memasuki tempat kerja terhadap bahaya dari akibat kecelakaan kerja.

\section{B. Tujuan Kesehatan dan Keselamatan Kerja}

Tujuan keselamatan kerja adalah untuk melindungi tenaga kerja atas hak keselamatan dan melakukan pekerjaan untuk kesejahteraan hidup dan meningkatkan produksi serta produktivitas nasional menjamin keselamatan setiap orang lain yang berada di tempat kerja dan dan melindungi sumber produksi Agar terpelihara dan dapat digunakan secara aman dan efisien.

Tujuan kesehatan dan keselamatan kerja menurut Mangkunegara (2002) :

1. Agar setiap pegawai mendapat jaminan kesehatan dan keselamatan kerja baik secara fisik, sosial dan psikologis.

2. Agar setiap perlengkapan dan peralatan kerja digunakan sebaik-baiknya dan seefektif mungkin.

3. Agar semua hasil produksi dipelihara keamanannya.

4. Agar adanya jaminan atas pemeliharaan dan peningkatan kesehatan gizi pegawai.

\section{Ruang Lingkup Kesehatan dan Keselamatan Kerja (K3)}

Ruang lingkup hyperkes dapat dijelaskan sebagai berikut (Rachman, 1990)

a. Kesehatan dan keselamatan kerja diterapkan di semua tempat kerja yang didalamnya melibatkan aspek manusia sebagai tenaga kerja, bahaya akibat kerja dan usaha yang dikerjakan. 
b. Aspek perlindungan dalam hyperkes meliputi:

1. Tenaga kerja dari semua jenis dan jenjang keahlian.

2. Peralatan dan bahan yang dipergunakan.

3. Faktor-faktor lingkungan fisik, biologi, kimiawi maupun sosial.

4. Proses produksi.

5. Karakteristik dan sifat pekerjaan.

6. Semua pihak yang terlibat dalam proses industri atau perusahaan ikut bertanggung jawab atas keberhasilan usaha hyperkes.

c. Penerapan hyperkes dilaksanakan secara holistik sejak perencanaan hingga perolehan hasil dari kegiatan industri barang maupun jasa.

d. Semua pihak yang terlibat dalam proses industri atau perusahaan ikut bertanggung jawab atas keberhasilan usaha hyperkes.

\section{Peran Perawat dalam Meningkatkan Kesehatan dan Keselamatan Kerja di Rumah Sakit (K3)}

Perawat harus memiliki kemampuan untuk memperhatikan orang lain, keterampilan intelektual, teknik dan interpersonal yang mencerminkan dalam perilaku perawat. Perawat memiliki peran kan dengan peningkatan kesehatan dan pencegahan penyakit dan menjalankan fungsi si sebagai pemberi perawatan, pembuat keputusan klinik dan etika, pelindung dan advokat bagi klien, manager kasus, rehabilitator, dan komunikator serta pendidik.

Di Rumah Sakit, zat berbahaya seperti cairan tubuh, obat-obat, cairan pembersih dan bahan kimia lainnya berada sangat dekat dengan banyak orang di sekitar Rumah Sakit termasuk perawat setiap harinya. Dengan demikian, di rumah sakit dapat terjadi tumpahan darah, cairan tubuh atau bahan kimia yang dapat terjadi kapan saja yang dapat disebabkan karena peralatan rusak atau rusak karena kesalahan manusia.

Penggunaan alat pelindung diri (APD) bertujuan untuk melindungi diri sendiri yang dalam hal merupakan petugas kesehatan dan juga untuk melindungi pasien dari infeksi mikroba patogen. Di rumah sakit mempunyai buku shop tersendiri yang berisikan standar alat dan juga langkah-langkah tindakan keperawatan yang harus diikuti oleh perawat dalam melakukan tugasnya. 
Untuk itu, peran yang dapat diambil perawat dalam meningkatkan kesehatan dan keselamatan kerja di rumah sakit adalah :

1. Perawat atau tim medis sebelum ataupun sesudah melakukan suatu tindakan, agar tetap mencuci tangan dengan 6 langkah benar mencuci tangan.

2. Perawat harus menggunakan alat proteksi diri atau APD sesuai dengan kebutuhan untuk melakukan suatu tindakan pemberian asuhan keperawatan kepada pasien.

3. Perawat melakukan segala tindakan pemberian asuhan keperawatan sesuai dengan SOP.

4. Perawat harus membuang sampah dengan benar sesuai dengan tempat yang telah ditentukan.

5. Managemen of Spillage.

6. Medication Safety (Keamanan Pengobatan)

\section{KESIMPULAN}

Kesehatan dan keselamatan kerja K3 adalah ilmu terapan yang bersifat multidisiplin, bidang yang terkait dengan kesehatan, keselamatan, dan kesejahteraan manusia yang bekerja di sebuah institusi maupun lokasi proyek.

Perawat merupakan suatu profesi yang memerlukan kesabaran dan ketenangan dalam melayani pasien yang sedang menderita sakit titik untuk itu Seorang perawat memerlukan kemampuan untuk memperhatikan orang lain, keterampilan intelektual teknikal dan interpersonal yang tercermin dalam perilaku perawat.

Kesehatan kerja adalah spesialisasi dalam ilmu kesehatan atau kedokteran beserta prakteknya yang bertujuan untuk pekerja atau masyarakat beserta memperoleh derajat kesehatan yang setinggi-tingginya, baik fisik mental sosial dengan usaha preventif dan kuratif terhadap penyakit penyakit atau gangguan kesehatan yang diakibatkan oleh faktor pekerjaan dan lingkungan kerja serta terhadap penyakit-penyakit umum.

Oleh karena itu, dalam melakukan pekerjaannya atau pemberian asuhan keperawatan oleh perawat kepada pasien, perawat harus memperhatikan beberapa peran yang harus dilakukan 
setiap kali memberi asuhan keperawatan kepada pasien, guna menghindari kecelakaan kerja yang tidak diharapkan.

\section{DAFTAR PUSTAKA}

1. Berliana, Ratih., Evi Widowati.2019.Tinjauan Sistem Manajemen Keselamatan dam Kesehatan Kerja pada Akreditasi Rumah Sakit.Jurnal HIGEIA Vol 3(3):492-503.

2. Hasibuan, Rahman.2017. Pengaruh Kesehatan dan Keselamatan Kerja, Pelatihan dan Kerja Tim Terhadap Kinerja Tenaga Medis di Rumah Sakit Budi Kemuliaan Batam.Jurnal DIMENSI VOL 6(2):323-340.

3. I, Silvia Maria P.,dkk.2015. Kejadian Kecelakaan Kerja Perawat Berdasarkan Tindakan Tidak Aman.Jurnal Care Vol 3 (2): 9-17.

4. Ismara, K Ima.,dkk.2014. Buku Ajar Keselamatan dan Kesehatan Kerja (K3).Tim K3 FT UNY (Universitas Negeri Yogyakarta). Hal 12.

5. Ivana, Azza.,dkk.2014. Analisa Komitmen Manajemen Rumah Sakit RS Terhadap Keselamatan dan Kesehatan Kerja K3 pada RS Prima Medika Pemalang.Jurnal Kesehatan Masyarakat (e-Journal) Vol 2 (1): 35-41.

6. Mantiri, Ezra Zimri Ruben Abiam.,dkk.2020. Faktor Psikologi dan Perilaku Dengan Penerapan Manajemen Keselamatan dan Kesehatan Kerja Rumah Sakit.Jurnal of Public Health and Community Medicine Vol 1(3): 19-27.

7. Nazirah, Riska., Yuswardi.2017. Perilaku Perawat dalam Penerapan Manajemen Kesehatan dan Keselamatan Kerja (K3) di Aceh.Idea Nursing Journal Vol VIII (3).

8. Nurmalia, Devi.,dkk.2019. Gambaran Penggunaan Alat Pelindung Diri oleh Perawat di Ruang Perawatan Rumah Sakit.Journal of Holistic Nursing and Health Science Vol $2(1): 45-53$.

9. Octavia, Widiwati Rinjani.,dkk.2018. Penerapan Pelayanan Kesehatan dan Keselamatan Kerja Pada Perawat di IGD Rumah Sakit Umum DR. Wahidin Sudiro Husodo Mojokerto Tahun 2017.Jurnal Gema Kesehatan Lingkungan Vol 16(1):101-109.

10. Purba, Hana Ike Dameria.,dkk.2018. Studi Kebijakan, Perencanaan dan Pelaksanaan Keselamatan Pasien dan Kesehatan Kerja Rumah Sakit (K3RS) di Rumah Sakit Umum 
(RSU) Mitra Sejati Medan Tahun 2018.Jurnal Mutiara Kesehatan Masyarakat Vol 3(2):113-124.

11. Putri, Oktaviana Zahratul.,dkk.2017. Analisis Risiko Keselamatan dan Kesehatan Kerja pada Petugas Kesehatan Instalasi Gawat Darurat Rumah Sakit Akademik UGM.Jurnal Kesehatan Vol 10 (1):1-12.

12. Redjeki, Sri.2016. Modul Bahan Ajar Cetak Farmasi : Kesehatan dan Keselamatan Kerja.Kebayoran Baru : Jakarta Selatan. Hal 6.

13. Simamora, R. H. (2018). Buku ajar keselamatan pasien melalui timbang terima pasien berbasis komunikasi efektif: SBAR. Medan: USUpress.

14. Simamora, R. H. (2019). Buku ajar pelaksanaan identifikasi pasien. Uwais Inspirasi Indonesia.
a. Kebijakan K3 yang berkaitan dengan keperawatan di Indonesia
b. K3 dalam keperawatan: pentingnya, tujuan, manfaat, \& etika
c. Ruang lingkup K3 dalam keperawatan

15. Tukatman.,dkk.2015. Analisis Keselamatan dan Kesehatan Kerja Perawat dalam Penanganan Pasien di Rumah Sakit Benyamin Guluh Kabupaten Kolaka.Jurnal Ners Vol $10(2): 343-347$. 